\title{
B-Cell Therapies in Multiple Sclerosis
}

\author{
Joseph J. Sabatino, Jr., Scott S. Zamvil, and Stephen L. Hauser \\ Multiple Sclerosis Center, Department of Neurology, University of California, San Francisco, California 94158 \\ Correspondence: jsabatino@ucsf.neuroimmunol.org
}

B cells play a vital function in multiple sclerosis (MS) pathogenesis through an array of effector functions. All currently approved MS disease-modifying therapies alter the frequency, phenotype, or homing of B cells in one way or another. The importance of this mechanism of action has been reinforced with the successful development and clinical testing of Bcell-depleting monoclonal antibodies that target the CD20 surface antigen. Ocrelizumab, a humanized anti-CD20 monoclonal antibody, was approved by the Food and Drug Administration (FDA) in March 2017 after pivotal trials showed dramatic reductions in inflammatory disease activity in relapsing MS as well as lessening of disability progression in primary progressive MS. These and other clinical studies place B cells at the center of the inflammatory cascade in MS and provide a launching point for development of therapies that target selective pathogenic B-cell populations.

$\mathrm{B}$ cells are considered major contributors to multiple sclerosis (MS) pathogenesis, a role that has taken on renewed importance with the advent of B-cell-depleting therapies. The majority of MS lesions contain infiltrating B cells with antibody deposition (Lucchinetti et al. 2001). Although animal models of MS have existed for decades, a key limitation was their inability to adequately recapitulate MS pathology. A startling finding was the ability of antimyelin antibodies to replicate MS-like lesions when cotransferred with myelin-reactive T cells (Genain et al. 1995; Hauser 2015). As our understanding of the mechanisms of MS pathology increases, it has become clear that the central role of B cells in MS is likely mediated through a number of effector functions.

Antibodies from cerebrospinal fluid (CSF)infiltrating plasmablasts and plasma cells produce oligoclonal bands (OCBs) (Obermeier et al. 2008; von Büdingen et al. 2010), a subset of which are reactive against myelin and other central nervous system (CNS) antigens (Warren et al. 1994; Genain et al. 1999) as well as other ubiquitous intracellular self-antigens (Brändle et al. 2016; Winger and Zamvil 2016). B-cellcontaining germinal centers in meningeal follicle-like structures, described in the CNS of secondary progressive MS (SPMS) patients (Serafini et al. 2004; Magliozzi et al. 2007), may be an additional source of OCB production. Some data also indicate that patients have higher serum titers of pathogenic antimyelin oligodendrocyte glycoprotein (MOG) antibodies compared to controls (Zhou et al. 2006). B cells in the CSF, CNS parenchyma, and meninges are clonally expanded, class-switched, and somatically hypermutated (Owens et al. 1998; Qin et al. 1998; Baranzini et al. 1999; Colombo et al. 2000; Ritchie et al. 2004; von Büdingen et al. 2012),

Editors: Howard L. Weiner and Vijay K. Kuchroo

Additional Perspectives on Multiple Sclerosis available at www.perspectivesinmedicine.org

Copyright (C 2019 Cold Spring Harbor Laboratory Press; all rights reserved; doi: 10.1101/cshperspect.a032037

Cite this article as Cold Spring Harb Perspect Med 2019;9:a032037 
J.J. Sabatino et al.

indicating antigen-driven stimulation likely occurs both in the CNS and periphery (von Büdingen et al. 2012; Bankoti et al. 2014; Palanichamy et al. 2014a; Stern et al. 2014).

$\mathrm{B}$ cells also play an important function as antigen-presenting cells (APCs). In animal models, major histocompatibility complex (MHC) II-expressing antigen-reactive $\mathrm{B}$ cells are crucial for CNS autoimmunity, and this effect is independent of soluble antibody production (Molnarfi et al. 2013). B cells that enter the CNS recruit other inflammatory cells, including $\mathrm{CD} 4^{+} \mathrm{T}$ cells and monocytes (Lehmann-Horn et al. 2015). B cells in MS patients express increased levels of costimulatory molecules (Genç et al. 1997; Aung and Balashov 2015), in particular in the CSF (Fraussen et al. 2016), which functions to increase the stimulation of antigen-reactive $T$ cells. Memory B cells from MS patients may have an enhanced ability to stimulate myelinreactive $\mathrm{T}$ cells (Harp et al. 2010). In addition, $B$ cells in MS patients secrete increased levels of proinflammatory interleukin (IL)-6 and granulocyte macrophage colony-stimulating factor (GM-CSF) (Barr et al. 2012; Li et al. 2015), which is correlated with increased proinflammatory $\mathrm{T}$ helper (Th) 17 cells in MS. Depletion of B cells in MS animal models results in reduced myelin-reactive Th1 and Th17 cells (Weber et al. 2010).

\section{CD20 DEPLETION THERAPIES: DAWN OF A NEW TREATMENT ERA IN MS}

Targeted depletion of $\mathrm{CD} 20^{+} \mathrm{B}$ cells has proven to be an extremely effective method of suppressing inflammatory activity in MS. Several different anti-CD20 monoclonal antibodies (mAbs) have been developed for MS treatment, including rituximab, ocrelizumab, and ofatumumab, which are described below in further detail. CD20 is a cell-surface molecule that functions as an ion channel and is expressed on most $\mathrm{B}$ cell subsets, including pre-B cells, immature, mature, and memory B cells. CD20 is not, however, expressed on pro-B cells, or on plasmablasts and plasma cells. Consequently, antiCD20 mAbs typically do not cause a reduction in serum immunoglobulin (Ig)G levels because of the sparing of plasma cells, although modest reductions in IgM levels can occur (Hauser et al. 2008).

Anti-CD20 therapies lead to rapid and near complete depletion of circulating $\mathrm{CD} 20^{+} \mathrm{B}$ cells, but with limited penetration of lymphoid tissues (Kamburova et al. 2013). Although rituximab does not efficiently cross the blood-brain barrier (BBB), it eliminates B cells in the CSF (Cross et al. 2006) and CNS perivascular space (Martin et al. 2009) without any detectable effect on the IgG index or oligoclonal bands (Cross et al. 2006; von Büdingen et al. 2016). In addition, $\mathrm{CD} 20^{+} \mathrm{B}$ cells are absent in the CNS perivascular space months after rituximab treatment (Martin et al. 2009). Following anti-CD20 depletion, repopulating $\mathrm{B}$ cells in the peripheral blood are comprised of primarily naïve and immature $B$ cells with fewer memory B cells and plasmablasts (Duddy et al. 2007; Hauser et al. 2008; Palanichamy et al. 2014b). Memory B cells appear to remain suppressed for at least 1-2 years following a single course of rituximab treatment (Roll et al. 2006; Palanichamy et al. 2014b). In addition, data indicate that reconstituted $\mathrm{B}$ cells following anti-CD20 therapy produce less proinflammatory GM-CSF, tumor necrosis factor (TNF)- $\alpha$, and lymphotoxin (LT) $\alpha$, and increased anti-inflammatory IL-10 (Duddy et al. 2007; Li et al. 2015).

Although recognized as a protein expressed by $\mathrm{B}$ cells, CD20 is also expressed at lower levels in $3 \%-5 \%$ of $\mathrm{CD}^{+} \mathrm{T}$ cells in the peripheral blood of healthy individuals (Palanichamy et al. 2014b; Schuh et al. 2016); these $\mathrm{CD}^{+}$ $\mathrm{CD} 20^{\mathrm{dim}}$ cells are possibly increased in MS patients (Palanichamy et al. 2014b). $\mathrm{CD}^{+}$ $\mathrm{CD} 20^{\mathrm{dim}} \mathrm{T}$ cells are also slightly more prevalent among $\mathrm{CD}^{+} \mathrm{T}$ cells compared to $\mathrm{CD} 4^{+} \mathrm{T}$ cells (Palanichamy et al. 2014b), and secrete more interferon (IFN) $\gamma$, tumor necrosis factor (TNF)- $\alpha$, IL-17, and IL-4 than $\mathrm{CD}^{+}{ }^{+} \mathrm{CD}_{2} 0^{-}$ $T$ cells (Schuh et al. 2016). In MS patients, and in other neurologic diseases, $\mathrm{CD} 20^{+} \mathrm{CD}^{+} \mathrm{T}$ cells are present at similar frequencies in CSF and peripheral blood (Schuh et al. 2016) CD20-expressing $\mathrm{T}$ cells are rapidly depleted by rituximab (Cross et al. 2006), but begin repopulating sooner than B cells (Palanichamy et al. 2014b; Schuh et al. 2016). Despite these 
interesting findings, the biologic relevance of $\mathrm{CD}^{+} 0^{+} \mathrm{T}$ cells in MS remains unclear. AntiCD20 treatment also significantly alters T-cell function beyond direct depletion of CD20-expressing T cells. Proliferation and proinflammatory IFN- $\gamma$ and IL- 17 production of $\mathrm{CD} 4^{+}$and $\mathrm{CD}^{+} \mathrm{T}$ cells are markedly reduced following rituximab treatment in MS patients (Bar-Or et al. 2010). In addition, some data suggest that regulatory $\mathrm{T}$ cells are increased following rituximab treatment of systemic lupus erythematosus (SLE) patients (Vallerskog et al. 2007). Taken together, it appears clear that anti-CD20 mAb produces profound quantitative and qualitative changes in both the humoral and cellular arms of the adaptive immune system and are the basis for their therapeutic efficacy in MS.

\section{RITUXIMAB}

Rituximab was initially developed for nonHodgkin's lymphoma and was the first antiCD20 mAb to be tested in MS. Rituximab is a mouse-human chimeric IgG1 antibody that eliminates circulating B cells via complementdependent cytotoxicity (CDC) and antibodydependent cellular cytotoxicity (ADCC). In a phase II double-blind placebo-controlled trial of relapsing remitting MS (RRMS) patients, a single course of rituximab ( $1 \mathrm{~g}$ given twice, 2 weeks apart) reduced newly enhancing lesions by more than $90 \%$, which was sustained at 48 weeks with a greater than $50 \%$ reduction in relapse rates (Hauser et al.2008). In a small study of 26 RRMS patients treated with two courses of rituximab, relapses were reduced by more than 80\% after 18 months (Bar-Or et al. 2008). RRMS patients who experienced breakthrough disease activity on glatiramer acetate (GA) or IFN- $\beta$ therapy experienced a $74 \%$ reduction in contrast-enhancing lesions following a single course of rituximab treatment, an effect that was evident as early as 12 weeks (Naismith et al. 2010). Given the impressive results of early clinical trials, rituximab has been used for years as an off-label therapy for MS patients. A retrospective analysis of over 550 RRMS patients treated with 500$1000 \mathrm{mg}$ rituximab every 6 to 12 months experienced an annual relapse rate of 0.044 or the equivalent of one relapse every 23 years (Salzer et al. 2016).

Transition from natalizumab to another disease-modifying therapy (DMT) has been notoriously challenging in MS given the risk for rebound disease activity following discontinuation of natalizumab. In a retrospective review of a Swedish registry, outcomes were compared for natalizumab-treated RRMS patients who were transitioned after John Cunningham (JC) virus seroconversion to either fingolimod or rituximab. Relapses and contrast-enhancing lesions occurred in $17.6 \%$ and $24.2 \%$ of fingolimod-treated patients, respectively, versus $1.8 \%$ and $1.4 \%$ of rituximab-treated patients, respectively (Alping et al. 2016). Despite these compelling data, rituximab ultimately did not proceed to phase III testing in MS because of complex factors, including patent life, other economic considerations, and the development of ocrelizumab.

\section{OCRELIZUMAB}

Ocrelizumab is a humanized anti-CD20 IgG1 $\mathrm{mAb}$ that leads to depletion of $\mathrm{CD} 20^{+} \mathrm{B}$ cells via ADCC and CDC activity, but with a greater role of the former mechanism because of a higher affinity for Fc $\gamma$ RIII receptors on natural killer (NK) cells. In a phase II trial, contrast-enhancing lesions in RRMS patients were reduced by $89 \%$ and $96 \%$ with $600 \mathrm{mg}$ and $2000 \mathrm{mg}$ ocrelizumab, respectively, compared to placebo at 24 weeks (Kappos et al. 2011). The annual relapse rate over 24 weeks was reduced by $86 \%$ and $73 \%$ with $600 \mathrm{mg}$ and $2000 \mathrm{mg}$ ocrelizumab, respectively, compared to placebo. More than $99 \%$ of B cells in the peripheral blood were depleted through 24 weeks for both doses of ocrelizumab (Kappos et al. 2011). Given the largely similar results with the two ocrelizumab doses, the lower dosage of $600 \mathrm{mg}$ (300 mg given twice over 2 weeks with subsequent redosing given as a single $600 \mathrm{mg}$ dose every 6 months) was chosen for the subsequent pivotal trials.

When ocrelizumab was tested in RRMS in two large phase III trials (termed OPERA I and II) a $46 \%-47 \%$ reduction in the annualized relapse rate was observed at 96 weeks compared to 


\section{J.J. Sabatino et al.}

$44 \mu \mathrm{g}$ IFN- $\beta$ - 1 a administered three times weekly (Hauser et al. 2017). Moreover, confirmed sustained disability progression at 12 and 24 weeks was $40 \%$ lower in the ocrelizumab-treated patients. $\mathrm{CD} 19^{+} \mathrm{B}$ cells remained undetectable through 96 weeks. The clinical benefits of ocrelizumab were paralleled by a $95 \%-97 \%$ reduction in contrast-enhancing lesions, a $97 \%$ $98 \%$ reduction in new or enlarging T2 lesions after week 24, and a higher proportion with improved brain volume loss compared to IFN- $\beta$-1a (Hauser et al. 2017). Forty-eight percent of ocrelizumab-treated patients achieved no evidence of disease activity ([NEDA] defined as no clinical relapse or disability progression and no radiological activity) compared to $25 \%-29 \%$ in the IFN$\beta$-treated patients (Hauser et al. 2017). The percent of patients achieving NEDA on ocrelizumab surpasses all other DMTs, including 33\% for fingolimod, 37\% for natalizumab, and 32\%-39\% for alemtuzumab.

In open-label extension studies of MS patients who received four courses of ocrelizumab, clinical and radiographic disease activity remained silent through 18 months after the last dose (Kappos et al. 2017). These effects mirror the prolonged suppression of memory $B$ cells after a single course of rituximab (Roll et al. 2006; Palanichamy et al. 2014b), suggesting possible resetting of the immune system long after anti-CD20 treatment. In contrast to natalizumab-treated MS patients, patients treated with rituximab and ocrelizumab do not develop rebound inflammation following B-cell reconstitution. Given these effects, it is intriguing to consider that a limited induction period (e.g., 2-3 years) of anti-CD20 treatment followed by surveillance might be an effective way to treat MS. Further study will be needed to determine whether this is a viable paradigm of disease control.

\section{OFATUMUMAB}

Ofatumumab is another anti-CD20 IgG1 mAb that binds a distinct epitope of CD20 compared to rituximab and ocrelizumab. Similar to rituximab, the mechanism of action of ofatumumab involves CDC more than ADCC. In a small clin- ical trial of 38 RRMS patients, several different doses $(100,300$, or $700 \mathrm{mg})$ of intravenous ofatumumab led to significant reductions in contrast-enhancing lesions and new or enlarging T2 lesions at 8-24 weeks (Sorensen et al. 2014). There was a modest reduction in relapses in the first 24 weeks for the low and medium doses, but no patients experienced any relapses at 6-12 months for any dose of ofatumumab. Although B-cell depletion was complete within 1 week of infusion of all doses, B-cell reconstitution began at 3-4 months in the low-dose group; B-cell depletion was persistent in the high dose at 24 weeks (Sorensen et al. 2014). Ofatumumab's formulation was subsequently modified to subcutaneous injections administered every 4 to 12 weeks. In a double-blind placebo-controlled trial of RRMS patients, subcutaneous ofatumumab was tested at doses of 3, 30, $60 \mathrm{mg}$ every 12 weeks or $60 \mathrm{mg}$ every 4 weeks (Bar-Or et al. 2014). A $65 \%$ reduction in new contrast-enhancing lesions was observed at all doses, with a greater than $90 \%$ reduction in enhancing lesions at 1-3 months. B cells were depleted and reconstituted in a dose-dependent manner, but B-cell repletion was not seen when dosing was given every 4 weeks (Bar-Or et al. 2014). Phase III testing of ofatumumab in RRMS is in progress.

\section{PROGRESSIVE MULTIPLE SCLEROSIS}

Despite major breakthroughs in the treatment of RRMS, primary progressive MS (PPMS), which affects $10 \%-15 \%$ of MS patients, has been a notoriously difficult form of MS to treat. Initial PPMS trials testing IFN- $\beta-1 a$, IFN- $\beta-1 b, G A$, and fingolimod all failed to meet their end points (Comi 2013; Montalban et al. 2017). Rituximab was tested in PPMS patients in a large randomized placebo-controlled trial; however, there was no change in time to confirmed disease progression sustained for 12 weeks (CDP12), which was the primary end point (Hawker et al. 2009). There was nonetheless a trend toward increased efficacy with rituximab (30.2\% with CDP12 vs. $38.5 \%$ for placebo). In preplanned subgroup analyses, patients with contrast-enhancing lesions and/or less than 51 years of age showed a delay in CDP12 (Hawker 
et al. 2009). In addition, rituximab-treated patients showed a reduction in $\mathrm{T} 2$ lesion volume, but no overall brain volume change compared to placebo (Hawker et al. 2009). In light of these findings, rituximab was not approved for PPMS, but continued to be used as an off-label therapy for certain patients. In a retrospective analysis of 67 PPMS as well as 198 SPMS patients treated with rituximab, the annualized relapse rates were 0.015 and 0.038 , respectively, and contrast-enhancing lesions occurred in $4 \%$ and $1 \%$, respectively (Salzer et al. 2016). Given that relapses and magnetic resonance imaging (MRI) contrast enhancement are less likely to occur in progressive MS, these findings are perhaps not surprising. In the same cohort of patients, the expanded disability status scale (EDSS) increased by 1.0 and 0.5 in PPMS and SPMS, respectively (Salzer et al. 2016).

Intravenous administration of rituximab leads to CSF concentrations that are approximately 1000-fold less than the plasma concentration (Petereit and Rubbert-Roth 2009). Thus, it seems plausible that progressive MS is driven by compartmentalized CNS inflammation that is resistant to intravenous anti-CD20 treatment, but might be amenable to intrathecal (IT) administration. IT rituximab leads to near complete depletion of B cells in the CSF and blood (Komori et al. 2015; Svenningsson et al. 2015) as well as reductions in certain IT cytokines (Studer et al. 2014). However, IT B-cell depletion was surprisingly transient (approximately 3 months), which was attributed to suboptimal CD20 saturation, partial ADCC killing, and poor CDC depletion of B cells in the CSF relative to the blood (Komori et al. 2015). In addition, markers for IT T-cell depletion and axonal injury did not change, and the trial was ultimately halted as part of the stopping criteria for failing to meet adequate biomarker goals of efficacy (Komori et al. 2015). The OCB pattern and IgG index were also unaffected in an SPMS patient who underwent two treatments of IT rituximab (Studer et al. 2014). That IT antibody production is unaffected by such potent interventions as intracranial radiation (Tourtellotte et al. 1980a), IT cytarabine (Tourtellotte et al. 1980b), and autologous hematopoietic stem- cell transplantation (Saiz et al. 2001; Nash et al 2003) is a testament to the difficulty of targeting the inflammatory process in the CNS and meninges.

A major advance in the treatment of PPMS occurred with the testing of ocrelizumab in a phase III randomized, placebo-controlled trial (Montalban et al. 2017). In this study, 732 PPMS patients (all younger than age 56, no history of relapses, EDSS of 3-6.5, and positive OCBs/IgG index in CSF) were randomized 2:1 to ocrelizumab (300 $\mathrm{mg}$ intravenous given 2 weeks apart every 24 weeks) or placebo for at least 120 weeks. There was a significant difference in the CDP12, the primary outcome of the study, with a $24 \%$ reduction in ocrelizumab-treated patients; there was also a $25 \%$ reduction in the CDP24 and a $29.3 \%$ reduction of worsening in the timed $25-\mathrm{ft}$ walk in ocrelizumab-treated patients (Montalban et al. 2017). There was also significant radiographic improvement in total lesion volume (3.4\% decrease in ocrelizumab vs. $7.4 \%$ increase in placebo) and brain volume loss (0.9\% decreased loss in ocrelizumab, $1.09 \%$ increased loss in placebo) (Montalban et al. 2017).

These results beg the question why ocrelizumab met multiple end points in PPMS, whereas rituximab showed a nonsignificant trend toward therapeutic benefit. One important difference is that the ocrelizumab PPMS study was approximately one-third larger than the rituximab study (732 compared to 439 patients, both with 2:1 enrollment into active treatment vs. placebo arms). There were also several differences in patient characteristics, including ocrelizumab patients being younger by an average of 5 years, having a shorter disease duration by 2.6 years, and having a slightly decreased EDSS ( 0.5 less) (Montalban et al. 2017) compared to rituximab patients (Hawker et al. 2009). In addition, ocrelizumab patients had nearly twice as many contrast-enhancing lesions at baseline compared to rituximab, but both groups ended up with similarly very low numbers of contrast-enhancing lesions at 12 weeks. Despite the rituximab data showing a nonsignificant $(p=0.14)$ trend toward reduced disability (Hawker et al. 2009), the CDP12 data for ocrelizumab and rituximab are fairly similar. Thus, both ocrelizu- 


\section{J.J. Sabatino et al.}

mab and rituximab provide a modest benefit in PPMS but ocrelizumab may be slightly superior. Whereas anti-CD20 therapies offer the first glimmers of hope for the treatment of progressive MS, their effects are somewhat limited and the need for more effective therapies remains.

\section{ADVERSE EFFECTS OF B-CELL DEPLETION}

Infusion reactions are the most common side effects of rituximab and ocrelizumab. In the phase II trial of rituximab in RRMS, 93\% of rituximab-treated patients experienced grade 1-2 infusion reactions, $7 \%$ experienced grade 3 , and none experienced grade 4 reactions (Hauser et al. 2008). Of note, no steroid pretreatment was given in these studies. In the ocrelizumab RRMS phase III trials, $34 \%$ of ocrelizumab-treated patients experienced infusion reactions, including one patient who experienced bronchospasm with recovery (Hauser et al. 2017). Infusion reactions with ocrelizumab were most often present with the initial dose and were less frequent with subsequent infusions and are likely the result of target cell lysis and effector cell cytokine release following Fc receptor ligation by antiCD20 mAb opsonized cells. Pretreatment with acetaminophen, antihistamine, and steroids is recommended to mitigate the frequency and severity of infusion reactions. Whereas rituximab is a mouse-human chimeric $\mathrm{mAb}$, ocrelizumab is a more fully humanized $\mathrm{mAb}$, which likely reduces the immunogenicity of the latter. This is reflected by the strikingly small percentage of ocrelizumab-treated patients $(0.4 \%)$ who develop antidrug antibodies (Hauser et al. 2017) compared to the nearly $30 \%$ of rituximab-treated patients (Bar-Or et al. 2008). However, in contrast to late serum sickness reactions mediated by preformed antibodies against administered drugs, early infusion-related reactions are thought to result from cell lysis and cytokine release mechanisms and have no correlation with antidrug antibodies.

Frequencies of infusion-related reactions with the various anti-CD20 antibodies have not been studied in a head-to-head fashion, and differences in protocols (for example, premedication with glucocorticoids in the ocrelizu- mab and ofatumumab, but not rituximab, studies) make cross-trial comparisons difficult. Ocrelizumab has greater ADCC than CDC activity, whereas the opposite is true for rituximab and ofatumumab. As CDC activity is believed to contribute prominently to infusion reactions (van der Kolk et al. 2001), ocrelizumab might be expected to have a more favorable mechanism of action in this regard.

Because of the profound depletion of circulating B cells, risk of infection is an important consideration in anti-CD20 therapy. In phase III trials, infections were reported in $57 \%-60 \%$ of ocrelizumab-treated RRMS patients compared to $53 \%-54 \%$ of IFN- $\beta-1$ a patients (Hauser et al. 2017); infections in the phase III PPMS were $71 \%$ in the ocrelizumab group and $70 \%$ in the placebo group (Montalban et al. 2017). Upper respiratory tract infections and nasopharyngitis were slightly more common in ocrelizumab-treated patients, but there was no difference in the frequency in serious infections in ocrelizumab and IFN- $\beta$ - 1 a patients (Hauser et al. 2017; Montalban et al. 2017). Given that clinical trials are relatively short in duration, infection risk after long-term CD20 depletion is unknown. Tuberculosis and hepatitis B reactivation are of particular concern with B-cell depletion, therefore prescreening for these infections is highly recommended. In addition, prescreening for hepatitis C and HIV are also recommended. Patients should undergo required vaccinations at least 6 weeks before anti-CD20 treatment and should not receive live vaccines in the setting of B-cell depletion.

Progressive multifocal leukoencephalopathy (PML) is a particularly feared complication of MS treatment since it was first reported in natalizumab-treated patients (KleinschmidtDeMasters and Tyler 2005; Langer-Gould et al. 2005). B cells are a cellular reservoir for JC virus dissemination to the CNS in PML (Durali et al. 2015), but much remains unknown about how or whether B-cell elimination alters PML risk and course. In rituximab-treated rheumatoid arthritis patients, the incidence of PML was estimated at 1 in 25,000 and prior immunosuppression was a significant risk factor (Clifford et al. 2011). Whether or to what extent rituximab con- 
tributes to PML risk in rheumatoid arthritis or other rheumatic diseases is unclear; unlike MS, these disorders are PML-associated and rituximab is also administered as an add-on therapy, generally with glucocorticoids and antimetabolites in combination. In retrospective analyses of over $800 \mathrm{MS}$ patients treated with rituximab for an average period of nearly 2 years, no PML cases were reported, despite $83 \%$ of patients being JC virus seropositive (Salzer et al. 2016). In addition, no cases of PML were reported in any of the ocrelizumab trials (Kappos et al. 2011; Hauser et al. 2017; Montalban et al. 2017). Nonetheless, the risk of PML associated with long-term B-cell depletion in MS is unknown. In addition, many patients who are JC virus seropositive and previously treated with PML-associated DMTs, such as natalizumab and fingolimod, will likely be transitioned to anti-CD20 therapies, and it is likely that "legacy" cases of PML will be reported in the future. Vigilance for PML in MS patients treated with anti-CD20 $\mathrm{mAb}$ is therefore recommended.

There was an unexpected imbalance in the incidence of malignancies observed in the ocrelizumab phase III trials. In the OPERA trials, four malignancies $(0.5 \%)$ occurred in ocrelizumab-treated patients (including two breast cancer cases) compared to two $(0.2 \%)$ in the IFN- $\beta$ 1a arms (Hauser et al. 2017); in the PPMS trial that enrolled 2:1 to either ocrelizumab or placebo, 11 malignancies $(2.3 \%)$ occurred in ocrelizumab-treated patients (including four breast cancer cases) compared to two (0.8\%) in the placebo arm (Montalban et al. 2017). The reason for the malignancy disparity with ocrelizumab is not clear, but there are several suggestions that it may not be clinically significant. First, the trend of increased malignancy, including breast cancer, has fallen in open-label extension studies (Kappos et al. 2017). In addition, the incidence of breast cancer of ocrelizumab-treated patients was not higher than epidemiologic expectations; in other words, breast cancer rates were less than expected in the control arms of the phase III ocrelizumab studies. Last, no changes in the risk of breast cancer or other malignancies has been noted with rituximab, which has been in clinical use since the late 1990s. Further study will be needed to determine whether there is in fact an altered risk of malignancy with ocrelizumab or other B-cell-directed therapies. In the interim, standard breast cancer screening guidelines are recommended for MS patients treated with ocrelizumab.

\section{THE EFFECTS OF OTHER MS DMTS ON B CELLS}

The success of anti-CD20 therapies in MS highlights the essential role of B cells in MS. In light of these effects, it is worth reviewing the effects of older MS disease modifying therapies as all impact the function, trafficking, or frequency of B cells (Claes et al. 2015; Longbrake and Cross 2016). The therapeutic efficacy of all DMTs in MS may therefore be a result, at least in part, of their effects on B cells.

\section{Interferons}

The IFNs have been shown to reduce the levels of costimulatory factors on B cells (Liu et al. 2001; Ramgolam et al. 2011), thereby decreasing the ability of B cells to simulate T cells. In addition, IFN- $\beta$ reduces Th17-inducing cytokines and increases anti-inflammatory IL-10 production by B cells (Ramgolam et al. 2011). IFN- $\beta$ also increases the frequency of transitional and regulatory B cells (Bregs) and reduces the frequency of class-switched memory B cells and plasmablasts (Schubert et al. 2015). These changes may be partly mediated by increased B-cell activating factor (BAFF) levels by IFN- $\beta$ treatment (Krumbholz et al. 2008a; Kannel et al. 2015). Notably, the therapeutic effect of IFN- $\beta$ in experimental autoimmune encephalomyelitis (EAE) is B-cell dependent (Schubert et al. 2015).

\section{Glatiramer Acetate}

GA treatment induces many of the same changes in B cells as the IFNs, including increased anti-inflammatory (IL-10) and reduced proinflammatory (TNF- $\alpha$, LT $\alpha$ ) cytokine levels in EAE (Kala et al. 2010) and MS (Ireland et al. 2014). GA treatment of EAE mice in vivo promotes development of IL-10-producing mono- 


\section{J.J. Sabatino et al.}

cytes (Weber et al. 2007) and induces anti-inflammatory B cells (Kala et al. 2010), leading to reductions in myelin-reactive $\mathrm{T}$-cell responses. Circulating total B cells as well as naïve B cells and plasmablasts are reduced in GA-treated MS patients, although there are conflicting reports on whether memory B cells are affected (Ireland et al. 2014; Rovituso et al. 2014). This effect on Bcell levels may be because of a reduction of BAFF levels in the CNS and BAFF receptor on $\mathrm{B}$ cells in GA-treated EAE (Begum-Haque et al. 2010).

Fingolimod, Dimethylfumarate (DMF), and Teriflunomide

Inhibition of sphingosine-1-phosphate (S1P) receptors by fingolimod leads to reduced circulating levels of all B-cell populations, including naïve and memory $B$ cells and plasmablasts. However, transitional/immature and naïve $B$ cells represent a higher proportion of B cells in the peripheral blood of fingolimod-treated MS patients and produce less TNF- $\alpha$ and increased IL-10 and TGF- $\beta$ (Miyazaki et al. 2014; Chiarini et al. 2015; Blumenfeld et al. 2016). DMF can induce lymphopenia, affecting $\mathrm{T}$ cells in particular, but also causes a modest reduction in circulating B-cell levels (Spencer et al. 2015; Lundy et al. 2016). DMF reduces memory more than naïve B-cell levels, reduces mature B-cell survival in vitro, and reduces proinflammatory GM-CSF, IL-6, and TNF- $\alpha$ production by B cells (Chi et al. 2011). DMF also reduces MHC II expression on $B$ cells and reduces the severity of B-cell-dependent EAE (Schulze-Topphoff et al. 2016). Teriflunomide inhibits the proliferation of both $\mathrm{B}$ and $T$ cells in vitro without affecting overall lymphocyte survival (Li et al. 2013).

\section{Natalizumab}

Natalizumab blocks VLA-4-mediated lymphocyte entry across the BBB into the CNS. VLA-4 is expressed on $B$ cells, in particular at higher levels on memory B cells compared to naïve $B$ cells (Silvy et al. 1997). In EAE, B-cell-specific VLA-4 deficiency leads to reduced disease severity and decreased Th17 and macrophage infiltration in the CNS (Lehmann-Horn et al.
2015). B-cell VLA-4 deficiency can also prevent accumulation of IL- $10^{+}$Bregs (Lehmann-Horn et al. 2016). In MS, natalizumab also reduces numbers of B cells in the CSF (Warnke et al. 2015) and has been reported to reduce the IgG index and OCBs transiently in some patients (Harrer et al. 2012; von Glehn et al. 2012; Mancuso et al. 2014; Warnke et al. 2015). Inhibition of B-cell CNS infiltration by natalizumab leads to an increase in peripheral circulating $B$ cells, in particular in pre- and newly produced B cells (Krumbholz et al. 2008b; Zanotti et al. 2012).

\section{Alemtuzumab}

Alemtuzumab is an anti-CD52 monoclonal antibody that depletes $\mathrm{B}$ cells and T cells via ADCC and CDC. B cells reconstitute earlier than T cells following alemtuzumab treatment and recover by 6 to 7 months (Thompson et al. 2010; HillCawthorne et al. 2012; Cossburn et al. 2013). Immature transitional B cells increase within 1 month of alemtuzumab treatment and, beyond 3 months, mature naïve $\mathrm{B}$ cells predominate over memory B cells (Thompson et al. 2010). BAFF levels are increased after 1 month of alemtuzumab, correlating with the surge in immature Bcell development (Thompson et al. 2010).

\section{Mitoxantrone}

Mitoxantrone is a potent immunosuppressant that was effective in a mixed population of relapsing and progressive MS patients (Millefiorini et al. 1997; Hartung et al. 2002), but has fallen out of favor because of cardiotoxicity and risk of leukemia from prolonged exposure (Marriott et al. 2010). B cells are preferentially depleted more than other lymphocytes following mitoxantrone treatment (Gbadamosi et al. 2003). Memory B cells are particularly reduced and B-cell production of IL-10 is increased, whereas TNF- $\alpha$ and LT $\alpha$ are decreased (Duddy et al. 2007).

\section{Atacicept: Lessons from an Unsuccessful B-Cell-Directed Therapy}

Atacicept is not approved for MS therapy and represents a negative clinical trial, but is none- 
theless noteworthy. Atacicept is a recombinant fusion protein of TACI-Fc IgG that binds the cytokines BAFF (also known as BLyS or B-lymphocyte stimulator) and a proliferation-inducing ligand (APRIL), thereby preventing their interaction with surface receptors on B cells. BAFF and APRIL are important for B-cell differentiation, maturation, and survival through interactions with several B-cell receptors, including the shared transmembrane activator and calcium modulator and cyclophilin-ligand interactor (TACI) receptor (Mackay and Browning 2002).

In a phase II trial, RRMS patients treated with weekly injections of atacicept experienced relapses at twice the rates compared to the placebo group, resulting in early termination of the study (Kappos et al. 2014). There was no difference between the treatment groups in the number of contrast-enhancing lesions, the primary end point of the study. In another phase II study of patients with a first event of optic neuritis (clinically isolated syndrome), twice as many atacicept-treated patients converted to clinically definite MS compared to placebo, again leading to early termination of the study (Sergott et al. 2015). From a biologic perspective, atacicept leads to partial depletion of B cells, with mature B-cell counts reduced by up to $60 \%-70 \%$ and significant reductions in IgM, IgA, and IgG levels (Kappos et al. 2014). After cessation of atacicept, relapse-rates normalized to those of placebo-treated patients, which was paralleled by the recovery of normal B-cell and immunoglobulin levels (Kappos et al. 2014).

These studies beg the question why partial B-cell depletion from atacicept worsened clinical MS activity. As outlined above, all the currently approved MS therapies skew B cells toward an anti-inflammatory/regulatory phenotype (IFNs, GA, fingolimod, DMF, mitoxantrone) or preferentially affect memory B cells (IFNs, fingolimod, DMF, natalizumab, alemtuzumab, mitoxantrone). Thus, there is increasing evidence that targeting the frequency, phenotype, or trafficking of memory B cells in particular is a key factor in effective MS immunotherapies (Baker et al. 2017). BAFF-treated B cells were skewed toward a regulatory phenotype and produced more IL-10, an effect that is abrogated by TACI-Fc (Yang et al. 2010), the same molecule as atacicept. In addition, TACI is preferentially expressed on memory B cells and plasmablasts (Baker et al. 2017), which may serve to explain the relative increase in memory B cells that occurs within weeks of a single dose of atacicept (Tak et al. 2008). It therefore seems likely that the worsening of MS activity that occurred with atacicept treatment resulted from a relative increase in memory B cells and/or reductions in Breg cells.

\section{NEW DIRECTIONS IN B-CELL-TARGETED THERAPIES IN MULTIPLE SCLEROSIS}

The clinical success of anti-CD20 mAbs and the failure of atacicept point to the promise as well as challenges of developing B-cell therapies for MS. Numerous studies using different approaches of targeting B cells in MS are in various stages of development. Ublituximab is yet another antiCD20 mAb that has shown excellent B-cell depletion using a rapid infusion protocol. MEDI551 is an anti-CD $19 \mathrm{mAb}$ that is designed to lead to more complete B-cell depletion as it targets $\mathrm{CD} 19^{+} \mathrm{CD} 20^{-}$pro-B cells, plasmablasts, and plasma cells. In phase I testing, MEDI-551 was well tolerated and led to prolonged B-cell depletion (Agius et al. 2015). Daratumumab is an anti-CD38 $\mathrm{mAb}$ approved for the treatment of multiple myeloma, a plasma cell malignancy, and is being considered for MS treatment. Additional therapies targeting the BAFF pathway, including anti-BAFF and anti-BAFF-R (VAY736) are underway. Small molecules targeting B-cell signaling, including ibrutinib (Bruton's tyrosine kinase inhibitor) and idealisib (PI3 kinase inhibitor) may provide novel mechanisms of targeting B cells and possibly other cells involved in immune pathogenesis.

There is no doubt that anti-CD20 therapies in MS have ushered in a new era in our understanding and treatment of relapsing and progressive MS. Never before have we appreciated the extent to which B cells contribute to MS pathogenesis, likely through myriad effector pathways both outside and within the CNS. DMTs like ocrelizumab offer a significant opportunity to shut down all metrics of inflamma- 
J.J. Sabatino et al.

tion in a substantial portion of RRMS patients. For the first time, a treatment for PPMS, albeit with modest effects, is now available. Numerous questions remain regarding anti-CD20 therapies, including how to optimize strategies with respect to treatment initiation (i.e., might earlier treatment be even more effective?) and dosing (can we develop biomarkers to guide the need for continued therapy?), as well as to determine effects on long-term disability (especially with respect to risk for SPMS) and long-term safety (including risk of malignancy, PML, or other adverse outcomes). Increased understanding of the antigenic targets of B cells, their phenotypes, and their interactions with $\mathrm{T}$ cells, the innate immune system, and various cells of the CNS, will hopefully provide unique opportunities for even more targeted, safe therapies in MS, and especially for development of more effective interventions to prevent and treat the progressive neurodegenerative phase of the disease.

\section{REFERENCES}

Agius M, Klodowska-Duda G, Maciejowski M, Potemkowski A, Sweeny S, Li J, Yao W, Patra K, Ratchford J, Katz E, et al. 2015. Safety and tolerability of MEDI-551 in patients with relapsing forms of multiple sclerosis: Results from a phase 1 randomised, placebo-controlled, escalating intravenous and subcutaneous dose study. ECTRIMS P528.

Alping P, Frisell T, Novakova L, Islam-Jakobsson P, Salzer J, Björck A, Axelsson M, Malmeström C, Fink K, Lycke J, et al. 2016. Rituximab versus fingolimod after natalizumab in multiple sclerosis patients. Ann Neurol 79: 950-958.

Aung LL, Balashov KE. 2015. Decreased Dicer expression is linked to increased expression of co-stimulatory molecule CD80 on B cells in multiple sclerosis. Mult Scler 21: 11311138.

Baker D, Marta M, Pryce G, Giovannoni G, Schmierer K. 2017. Memory B cells are major targets for effective immunotherapy in relapsing multiple sclerosis. EBioMedicine 16: 41-50.

Bankoti J, Apeltsin L, Hauser SL, Allen S, Albertolle ME, Witkowska HE, Von Büdingen HC. 2014. In multiple sclerosis, oligoclonal bands connect to peripheral B-cell responses. Ann Neurol 75: 266-276.

Baranzini S, Jeong M, Butunoi C, Murray R, Bernard C, Oksenberg J. 1999. B cell repertoire diversity and clonal expansion in multiple sclerosis brain lesions. J Immunol 163: 5133-5144.

Bar-Or A, Calabresi PAJ, Arnold D, Markowitz C, Shafer S, Kasper LH, Waubant E, Gazda S, Fox RJ, Panzara M, et al. 2008. Rituximab in relapsing-remitting multiple sclerosis: A 72-week, open-label, phase I trial. Ann Neurol 63: 395400.
Bar-Or A, Fawaz L, Fan B, Darlington PJ, Rieger A, Ghorayeb C, Calabresi PA, Waubant E, Hauser SL, Zhang J, et al. 2010. Abnormal B-cell cytokine responses a trigger of T-cell-mediated disease in MS? Ann Neurol 67: 452-461.

Bar-Or A, Groves R, Austin D, Tolson J, Vanmeter S, Lewis E, Sorensen PS. 2014. The MIRROR Study: A randomized, double-blind, placebo-controlled, parallel-group, dose-ranging study to investigate the safety and MRI efficacy of subcutaneous ofatumumab in subjects with relapsing-remitting multiple sclerosis (RRMS). Neurology 82 (10 Suppl).

Barr TA, Shen P, Brown S, Lampropoulou V, Roch T, Lawrie S, Fan B, O'Connor RA, Anderton SM, Bar-Or A, et al. 2012. B cell depletion therapy ameliorates autoimmune disease through ablation of IL-6-producing B cells. J Exp Med 209: 1001-1010.

Begum-Haque S, Sharma A, Christy M, Lentini T, OchoaReparaz J, Fayed IF, Mielcarz D, Haque A, Kasper LH. 2010. Increased expression of B cell-associated regulatory cytokines by glatiramer acetate in mice with experimental autoimmune encephalomyelitis. J Neuroimmunol 219: $47-53$.

Blumenfeld S, Staun-Ram E, Miller A. 2016. Fingolimod therapy modulates circulating B cell composition, increases $B$ regulatory subsets and production of IL-10 and TGF $\beta$ in patients with multiple sclerosis. J Autoimmun 70: 40-51.

Brändle SM, Obermeier B, Senel M, Bruder J, Mentele R, Khademi M, Olsson T, Tumani H, Kristoferitsch W, Lottspeich F, et al. 2016. Distinct oligoclonal band antibodies in multiple sclerosis recognize ubiquitous self-proteins. Proc Natl Acad Sci 113: 7864-7869.

Chi Y, Fan Y, He L, Liu W, Wen X, Zhou S, Wang X, Zhang C, Kong H, Sonoda L, et al. 2011. Novel role of aquaporin-4 in $\mathrm{CD}^{+} \mathrm{CD} 25^{+} \mathrm{T}$ regulatory cell development and severity of Parkinson's disease. Aging Cell 10: 368-382.

Chiarini M, Sottini A, Bertoli D, Serana F, Caimi L, Rasia S, Capra R, Imberti L. 2015. Newly produced T and B lymphocytes and T-cell receptor repertoire diversity are reduced in peripheral blood of fingolimod-treated multiple sclerosis patients. Mult Scler 21: 726-34.

Claes N, Fraussen J, Stinissen P, Hupperts R, Somers V. 2015. $\mathrm{B}$ cells are multifunctional players in multiple sclerosis pathogenesis: Insights from therapeutic interventions. Front Immunol 6: 642.

Clifford DB, Ances B, Costello C, Rosen-Schmidt S, Andersson M, Parks D, Perry A, Yerra R, Schmidt R, Alvarez E, et al. 2011. Rituximab-associated progressive multifocal leukoencephalopathy in rheumatoid arthritis. Arch Neurol 68: 1156-1164.

Colombo M, Dono M, Gazzola P, Roncella S, Valetto A, Chiorazzi N, Mancardi GL, Ferrarini M. 2000. Accumulation of clonally related B lymphocytes in the cerebrospinal fluid of multiple sclerosis patients. J Immunol 164: 2782-2789.

Comi G. 2013. Disease-modifying treatments for progressive multiple sclerosis. Mult Scler J 19: 1428-1436.

Cossburn MD, Harding K, Ingram G, El-Shanawany T, Heaps A, Pickersgill TP, Jolles S, Robertson NP. 2013 Clinical relevance of differential lymphocyte recovery after alemtuzumab therapy for multiple sclerosis. Neurology 80: 55-61. 
Cross AH, Stark JL, Lauber J, Ramsbottom MJ, Lyons JA 2006. Rituximab reduces B cells and T cells in cerebrospinal fluid of multiple sclerosis patients. J Neuroimmunol 180: $63-70$.

Duddy M, Niino M, Adatia F, Hebert S, Freedman M, Atkins H, Kim HJ, Bar-Or A. 2007. Distinct effector cytokine profiles of memory and naïve human B cell subsets and implication in multiple sclerosis. J Immunol 178: 60926099.

Durali D, de Goër de Herve MG, Gasnault J, Taoufik Y. 2015. $\mathrm{B}$ cells and progressive multifocal leukoencephalopathy: Search for the missing link. Front Immunol 6: 241.

Fraussen J, Claes N, Van Wijmeersch B, van Horssen J, Stinissen P, Hupperts R, Somers V. 2016. B cells of multiple sclerosis patients induce autoreactive proinflammatory T cell responses. Clin Immunol 173: 1-9.

Gbadamosi J, Buhmann C, Tessmer W, Moench A, Haag F, Heesen C. 2003. Effects of mitoxantrone on multiple sclerosis patients' lymphocyte subpopulations and production of immunoglobulin, TNF- $\alpha$ and IL-10. Eur Neurol 49: $137-141$.

Genain CP, Nguyen M, Letvin NL, Pearl R, Davis RL, Adelman M, Lees MB, Linington C, Hauser SL. 1995. Antibody facilitation of multiple sclerosis like lesions in a nonhuman primate. J Clin Invest 96: 2966-2974.

Genain CP, Cannella B, Hauser SL, Raine CS. 1999. Identification of autoantibodies associated with myelin damage in multiple sclerosis. Nat Med 5: 170-175.

Genç K, Dona DL, Reder AT. 1997. Increased CD80 ${ }^{+}$B cells in active multiple sclerosis and reversal by interferon $\beta-1 \mathrm{~b}$ therapy. J Clin Invest 99: 2664-2671.

Harp CT, Ireland S, Davis LS, Remington G, Cassidy B, Cravens PD, Stuve O, Lovett-Racke AE, Eagar TN, Greenberg BM, et al. 2010. Memory B cells from a subset of treatment-naïve relapsing-remitting multiple sclerosis patients elicit $\mathrm{CD} 4^{+}$T-cell proliferation and IFN- $\gamma$ production in response to myelin basic protein and myelin oligodendrocyte glycoprotein. Eur J Immunol 40: 29422956.

Harrer A, Tumani H, Niendorf S, Lauda F, Geis C, Weishaupt A, Kleinschnitz C, Rauer S, Kuhle J, Stangel M, et al. 2012. Cerebrospinal fluid parameters of B cell-related activity in patients with active disease during natalizumab therapy. Mult Scler J 19: 1209-1212.

Hartung H-P, Gonsette R, Konig N, Kwiecinski H, Guseo A, Morrissey SP, Krapf H, Zwingers T. 2002. Mitoxantrone in progressive multiple sclerosis: A placebo-controlled, double-blind, randomised, multicentre trial. Lancet 360: 2018-2025.

Hauser SL. 2015. The Charcot Lecture | Beating MS: A story of B cells, with twists and turns. Mult Scler J 21: 8-21.

Hauser S, Waubant E, Arnold DL, Vollmer T, Antel J, Fox RJ, Bar-Or A, Panzara M, Sarkar N, Ph D, et al. 2008. B-cell depletion with rituximab in relapsing-remitting multiple sclerosis. N Engl J Med 358: 676-688.

Hauser SL, Bar-Or A, Comi G, Giovannoni G, Hartung H-P, Hemmer B, Lublin F, Montalban X, Rammohan KW, Selmaj K, et al. 2017. Ocrelizumab versus Interferon $\beta$ 1a in relapsing multiple sclerosis. $N$ Engl J Med 376: 221234.

Hawker K, O'Connor P, Freedman MS, Calabresi PA, Antel J, Simon J, Hauser S, Waubant E, Vollmer T, Panitch H, et al. 2009. Rituximab in patients with primary progressive multiple sclerosis: Results of a randomized double-blind placebo-controlled multicenter trial. Ann Neurol 66: 460471.

Hill-Cawthorne GA, Button T, Tuohy O, Jones JL, May K, Somerfield J, Green A, Giovannoni G, Compston AS, Fahey MT, et al. 2012. Long term lymphocyte reconstitution after alemtuzumab treatment of multiple sclerosis. J Neurol Neurosurg Psychiatry 83: 298-304.

Ireland SJ, Guzman AA, O'Brien DE, Hughes S, Greenberg B, Flores A, Graves D, Remington G, Frohman EM, Davis LS, et al. 2014. The effect of glatiramer acetate therapy on functional properties of $\mathrm{B}$ cells from patients with relapsing-remitting multiple sclerosis. JAMA Neurol 71: 14211428.

Kala M, Rhodes SN, Piao WH, Shi FD, Campagnolo DI, Vollmer TL. 2010. B cells from glatiramer acetate-treated mice suppress experimental autoimmune encephalomyelitis. Exp Neurol 221: 136-145.

Kamburova EG, Koenen HJPM, Borgman KJE, Ten Berge IJ, Joosten I, Hilbrands LB. 2013. A single dose of rituximab does not deplete B cells in secondary lymphoid organs but alters phenotype and function. Am J Transplant 13: 1503-1511.

Kannel K, Alnek K, Vahter L, Gross-Paju K, Uibo R, Kisand KV. 2015. Changes in blood B cell-activating factor (BAFF) levels in multiple sclerosis: A sign of treatment outcome. PLoS ONE 10: 1-16.

Kappos L, Li D, Calabresi PA, O'Connor P, Bar-Or A, Barkhof F, Yin M, Leppert D, Glanzman R, Tinbergen J, et al. 2011. Ocrelizumab in relapsing-remitting multiple sclerosis: A phase 2, randomised, placebo-controlled, multicentre trial. Lancet 378: 1779-1787.

Kappos L, Hartung HP, Freedman MS, Boyko A, Radü EW, Mikol DD, Lamarine M, Hyvert Y, Freudensprung U, Plitz T, et al. 2014. Atacicept in multiple sclerosis (ATAMS): A randomised, placebo-controlled, doubleblind, phase 2 trial. Lancet Neurol 13: 353-363.

Kappos L, Hauser S, Montalban X, Buffels R, Chin P, Li P, Li C, Mortensen D, Napieralski J, Van Beek J, et al. 2017. Safety of ocrelizumab in multiple sclerosis: Updated analysis in patients with relapsing and primary progressive multiple sclerosis. Neurology 88: P5.407.

Kleinschmidt-DeMasters BK, Tyler KL. 2005. Progressive multifocal leukoencephalopathy complicating treatment with natalizumab and interferon $\beta$-1a for multiple sclerosis. N Engl J Med 353: 369-374.

Komori M, Blake A, Greenwood M, Lin YC, Kosa P, Ghazali D, Winokur P, Natrajan M, Wuest SC, Romm E, et al. 2015. Cerebrospinal fluid markers reveal intrathecal inflammation in progressive multiple sclerosis. Ann Neurol 78: 3-20.

Krumbholz M, Faber H, Steinmeyer F, Hoffmann LA, Kümpfel T, Pellkofer H, Derfuss T, Ionescu C, Starck $M$, Hafner $C$, et al. 2008a. Interferon- $\beta$ increases BAFF levels in multiple sclerosis: Implications for B cell autoimmunity. Brain 131: 1455-1463.

Krumbholz M, Meinl I, Kümpfel T, Hohlfeld R, Meinl E. 2008b. Natalizumab disproportionately increases circulating pre-B and B cells in multiple sclerosis. Neurology 71: $1350-1354$. 
J.J. Sabatino et al.

Langer-Gould A, Atlas SW, Green AJ, Bollen AW, Pelletier D. 2005. Progressive multifocal leukoencephalopathy in a patient treated with natalizumab. N Engl J Med 353: 375381.

Lehmann-Horn K, Sagan SA, Bernard CCA, Sobel RA, Zamvil SS. 2015. B-cell very late antigen-4 deficiency reduces leukocyte recruitment and susceptibility to central nervous system autoimmunity. Ann Neurol 77: 902-908.

Lehmann-Horn K, Sagan SA, Winger RC, Spencer CM, Bernard CCA, Sobel RA, Zamvil SS. 2016. CNS accumulation of regulatory B cells is VLA-4-dependent. Neurol Neuroimmunol Neuroinflamm 3: e212.

Li L, Liu J, Delohery T, Zhang D, Arendt C, Jones C. 2013. The effects of teriflunomide on lymphocyte subpopulations in human peripheral blood mononuclear cells in vitro. J Neuroimmunol 265: 82-90.

Li R, Rezk A, Miyazaki Y, Hilgenberg E, Touil H, Shen P, Moore CS, Michel L, Althekair F, Rajasekharan S, et al. 2015. Proinflammatory GM-CSF-producing B cells in multiple sclerosis and B cell depletion therapy. Sci Transl Med 7: 310ra166.

Liu Z, Pelfrey CM, Cotleur A, Lee JC, Rudick RA. 2001. Immunomodulatory effects of interferon $\beta$-1a in multiple sclerosis. J Neuroimmunol 112: 153-162.

Longbrake EE, Cross AH. 2016. Effect of multiple sclerosis disease-modifying therapies on B cells and humoral immunity. JAMA Neurol 73: 219-225.

Lucchinetti CF, Brück W, Parisi JE, Scheithauer B, Rodriguez M, Lassmann H, Bruck W, Parisi JE, Scheithauter B Rodriguez M, et al. 2001. Heterogenity of multiple sclerosis lesions: Implication for the pathogenesis of demyelination. Ann Neurol 47: 707-717.

Lundy SK, Wu Q, Wang Q, Dowling CA, Taitano SH, Mao G, Mao-Draayer Y. 2016. Dimethyl fumarate treatment of relapsing-remitting multiple sclerosis influences B-cell subsets. Neurol Neuroimmunol Neuroinflamm 3: e211.

Mackay F, Browning JL. 2002. BAFF: A fundamental survival factor for B cells. Nat Rev Immunol 2: 465-475.

Magliozzi R, Howell O, Vora A, Serafini B, Nicholas R, Puopolo M, Reynolds R, Aloisi F. 2007. Meningeal B-cell follicles in secondary progressive multiple sclerosis associate with early onset of disease and severe cortical pathology. Brain 130: 1089-1104.

Mancuso R, Franciotta D, Rovaris M, Caputo D, Sala A, Hernis A, Agostini S, Calvo M, Clerici M. 2014. Effects of natalizumab on oligoclonal bands in the cerebrospinal fluid of multiple sclerosis patients: A longitudinal study. Mult Scler 20: 1900-1903.

Marriott JJ, Miyasaki JM, Gronseth G, O'Connor PW. 2010 Evidence Report: The efficacy and safety of mitoxantrone (Novantrone) in the treatment of multiple sclerosis: Report of the Therapeutics and Technology Assessment Subcommittee of the American Academy of Neurology. Neurology 74: 1463-1470.

Martin M del P, Cravens PD, Winger R, Kieseier BC, Cepok S, Eagar TN, Zamvil SS, Weber MS, Frohman EM, Kleinschmidt-DeMasters BK, et al. 2009. Depletion of B lymphocytes from cerebral perivascular spaces by rituximab. Arch Neurol 66: 1016-1021.

Millefiorini E, Gasperini C, Pozzilli C, D’Andrea F, Bastianello S, Trojano M, Morino S, Brescia Morra V, Bozzao A Calo’ A, et al. 1997. Randomized placebo-controlled trial of mitoxantrone in relapsing-remitting multiple sclerosis: 24-month clinical and MRI outcome. J Neurol 244: 153 159.

Miyazaki Y, Niino M, Fukazawa T, Takahashi E, Nonaka T, Amino I, Tashiro J, Minami N, Fujiki N, Doi S, et al. 2014. Suppressed pro-inflammatory properties of circulating B cells in patients with multiple sclerosis treated with fingolimod, based on altered proportions of B-cell subpopulations. Clin Immunol 151: 127-135.

Molnarfi N, Schulze-Topphoff U, Weber MS, Patarroyo JC, Prod'homme T, Varrin-Doyer M, Shetty A, Linington C, Slavin AJ, Hidalgo J, et al. 2013. MHC class II-dependent $\mathrm{B}$ cell APC function is required for induction of CNS autoimmunity independent of myelin-specific antibodies. J Exp Med 210: 2921-2937.

Montalban X, Hauser SL, Kappos L, Arnold DL, Bar-Or A, Comi G, de Seze J, Giovannoni G, Hartung HP, Hemmer B, et al. 2017. Ocrelizumab versus placebo in primary progressive multiple sclerosis. NEngl J Med 376: 209-220.

Naismith RT, Piccio L, Lyons JA, Lauber J, Tutlam NT, Parks BJ, Trinkaus K, Song SK, Cross AH. 2010. Rituximab addon therapy for breakthrough relapsing multiple sclerosis. Neurology 74: 1860-1867.

Nash RA, Bowen JD, McSweeney PA, Pavletic SZ, Maravilla KR, Park M, Storek J, Sullivan KM, Al-Omaishi J, Corboy JR, et al. 2003. High-dose immunosuppressive therapy and autologous peripheral blood stem cell transplantation for severe multiple sclerosis. Blood 102: 2364-2372.

Obermeier B, Mentele R, Malotka J, Kellermann J, Kümpfel T, Wekerle H, Lottspeich F, Hohlfeld R, Dornmair K. 2008. Matching of oligoclonal immunoglobulin transcriptomes and proteomes of cerebrospinal fluid in multiple sclerosis. Nat Med 14: 688-693.

Owens GP, Kraus H, Burgoon MP, Smith-Jensen T, Devlin ME, Gilden DH. 1998. Restricted use of $\mathrm{V}_{\mathrm{H}} 4$ germline segments in an acute multiple sclerosis brain. Ann Neurol 43: $236-243$.

Palanichamy A, Apeltsin L, Kuo TC, Sirota M, Wang S, Pitts SJ, Sundar PD, Telman D, Zhao LZ, Derstine M, et al. 2014a. Immunoglobulin class-switched B cells form an active immune axis between CNS and periphery in multiple sclerosis. Sci Transl Med 6: 248ra106.

Palanichamy A, Jahn S, Nickles D, Derstine M, Abounasr A, Hauser SL, Baranzini SE, Leppert D, von Büdingen HC. 2014b. Rituximab efficiently depletes increased CD20-expressing $\mathrm{T}$ cells in multiple sclerosis patients. J Immunol 193: $580-586$.

Petereit HF, Rubbert-Roth A. 2009. Rituximab levels in cerebrospinal fluid of patients with neurological autoimmune disorders. Mult Scler 15: 189-192.

Qin Y, Zhang Y, Talbot P, Poole R, Antel J. 1998. Clonal expansion and somatic mutation of $\mathrm{VH}$ genes of $\mathrm{B}$ cells from the cerebrospinal fluid of multiple sclerosis. J Neuroimmunol 90: 77.

Ramgolam VS, Sha Y, Marcus KL, Choudhary N, Troiani L, Chopra M, Markovic-Plese S. 2011. B cells as a therapeutic target for IFN- $\beta$ in relapsing-remitting multiple sclerosis. J Immunol 186: 4518-4526.

Ritchie AM, Gilden DH, Williamson RA, Burgoon MP, Yu X, Helm K, Corboy JR, Owens GP. 2004. Comparative analysis of the $\mathrm{CD} 19^{+}$and $\mathrm{CD} 138^{+}$cell antibody reper- 
toires in the cerebrospinal fluid of patients with multiple sclerosis. J Immunol 173: 649-656.

Roll P, Palanichamy A, Kneitz C, Dorner T, Tony HP. 2006. Regeneration of $\mathrm{B}$ cell subsets after transient $\mathrm{B}$ cell depletion using anti-CD20 antibodies in rheumatoid arthritis. Arthritis Rheum 54: 2377-2386.

Rovituso D, Heller S, Schroeter M, Kleinschnitz C, Kuerten S. 2014. B1 cells are unaffected by immune modulatory treatment in remitting-relapsing multiple sclerosis patients. J Neuroimmunol 272: 86-90.

Saiz A, Carreras E, Berenguer J, Yagüe J, Martínez C, Marín P, Rovira M, Pujol T, Arbizu T, Graus F. 2001. MRI and CSF oligoclonal bands after autologous hematopoietic stem cell transplantation in MS. Neurology 56: 1084 1089.

Salzer J, Svenningsson R, Alping P, Novakova L, Björck A, Fink K, Islam-Jakobsson P, Malmeström C, Axelsson M, Vågberg M, et al. 2016. Rituximab in multiple sclerosis: A retrospective observational study on safety and efficacy. Neurology 87: 2074-2081.

Schubert RD, Hu Y, Kumar G, Szeto S, Abraham P, Winderl J, Guthridge JM, Pardo G, Dunn J, Steinman L, et al. 2015. IFN- $\beta$ treatment requires $B$ cells for efficacy in neuroautoimmunity. J Immunol 194: 2110-2116.

Schuh E, Berer K, Mulazzani M, Feil K, Meinl I, Lahm H, Krane M, Lange R, Pfannes K, Subklewe M, et al. 2016. Features of human $\mathrm{CD}^{+} \mathrm{CD} 20^{+} \mathrm{T}$ Cells. J Immunol 187: 1111-1117.

Schulze-Topphoff U, Varrin-Doyer M, Pekarek K, Spencer CM, Shetty A, Sagan SA, Cree BA, Sobel RA, Wipke BT, Steinman L, et al. 2016. Dimethyl fumarate treatment induces adaptive and innate immune modulation independent of Nrf2. Proc Natl Acad Sci 113: 4777-4782.

Serafini B, Rosicarelli B, Magliozzi R, Stigliano E, Aloisi F. 2004. Detection of ectopic B-cell follicles with germinal centers in the meninges of patients with secondary progressive multiple sclerosis. Brain Pathol 14: 164-174.

Sergott RC, Bennett JL, Rieckmann P, Montalban X, Mikol D, Freudensprung U, Plitz T, Van Beek J. 2015. ATON Results from a phase II randomized trial of the B-celltargeting agent atacicept in patients with optic neuritis J Neurol Sci 351: 174-178.

Silvy A, Altevogt P, Mondikre P, Bella C. 1997. A role for the VLA-4 integrin in the activation of human memory $\mathrm{B}$ cells. Eur J Immunol 27: 2757-2764.

Sorensen PS, Lisby S, Grove R, Derosier F, Shackelford S, Havrdova E, Drulovic J, Filippi M. 2014. Safety and efficacy of ofatumumab in relapsing-remitting multiple sclerosis: A phase 2 study. Neurology 82: 573-581.

Spencer CM, Crabtree-Hartman EC, Lehmann-Horn K Cree BA, Zamvil SS. 2015. Reduction of CD8 ${ }^{+}$T lymphocytes in multiple sclerosis patients treated with dimethyl fumarate. Neurol Neuroimmunol Neuroinflamm 2: e76.

Stern JNH, Yaari G, Vander Heiden JA, Church G, Donahue WF, Hintzen RQ, Huttner AJ, Laman JD, Nagra RM, Nylander A, et al. 2014. B cells populating the multiple sclerosis brain mature in the draining cervical lymph nodes. Sci Transl Med 6: 248ra107.

Studer V, Rossi S, Motta C, Buttari F, Centonze D. 2014 Peripheral B cell depletion and central proinflammatory cytokine reduction following repeated intrathecal admin- istration of rituximab in progressive multiple sclerosis. $J$ Neuroimmunol 276: 229-231.

Svenningsson A, Bergman J, Dring A, Vågberg M, Birgander R, Lindqvist T, Gilthorpe J, Bergenheim T. 2015. Rapid depletion of B lymphocytes by ultra-low-dose rituximab delivered intrathecally. Neurol Neuroimmunol Neuroinflamm 2: e79.

Tak PP, Thurlings RM, Rossier C, Nestorov I, Dimic A, Mircetic V, Rischmueller M, Nasonov E, Shmidt E, Emery P, et al. 2008. Atacicept in patients with rheumatoid arthritis: Results of a multicenter, phase Ib, double-blind, placebo-controlled, dose-escalating, single- and repeateddose study. Arthritis Rheum 58: 61-72.

Thompson SAJ, Jones JL, Cox AL, Compston DAS, Coles AJ. 2010. B-Cell reconstitution and BAFF after alemtuzumab (Campath-1H) treatment of multiple sclerosis. J Clin Immunol 30: 99-105.

Tourtellotte WW, Potvin AR, Baumhefner RW, Potvin JH, Ma BI, Syndulko K, Petrovich Z. 1980a. Multiple sclerosis de novo CNS IgG synthesis: Effect of CNS irradiation. Arch Neurol 37: 620-624.

Tourtellotte WW, Potvin AR, Mendez M, Baumhefner RW, Potvin JH, Ma BI, Syndulko K. 1980b. Failure of intravenous and intrathecal cytarabine to modify central nervous system IgG synthesis in multiple sclerosis. Ann Neurol 8: 402-408.

Vallerskog T, Gunnarsson I, Widhe M, Risselada A, Klareskog L, van Vollenhoven R, Malmström V, Trollmo C. 2007. Treatment with rituximab affects both the cellular and the humoral arm of the immune system in patients with SLE. Clin Immunol 122: 62-74.

van der Kolk LE, Grillo-Lopez AJ, Baars JW, Hack CE, van Oers MHJ. 2001. Complement activation plays a key role in the side-effects of rituximab treatment. Br J Haematol 115: $807-811$.

von Büdingen HC, Gulati M, Kuenzle S, Fischer K, Rupprecht TA, Goebels N. 2010. Clonally expanded plasma cells in the cerebrospinal fluid of patients with central nervous system autoimmune demyelination produce "oligoclonal bands." J Neuroimmunol 218: 134-139.

von Büdingen H-C, Kuo TC, Sirota M, Van Belle CJ, Apeltsin L, Glanville J, Cree BA, Gourraud P, Schwartzburg A, Huerta G, et al. 2012. B cell exchange across the bloodbrain barrier in multiple sclerosis. J Clin Invest 122: 24 28.

von Büdingen H-C, Bischof A, Eggers EL, Wang S, Bevan CJ, Cree BAC, Henry RG, Hauser SL. 2016. Onset of secondary progressive MS after long-term rituximab therapy-A case report. Ann Clin Transl Neurol 41:

von Glehn F, Farias AS, de Oliveira ACP, Damasceno A, Longhini ALF, Oliveira EC, Damasceno BP, Santos LM, Brandao CO. 2012. Disappearance of cerebrospinal fluid oligoclonal bands after natalizumab treatment of multiple sclerosis patients. Mult Scler J 18: 1038-1041.

Warnke C, Stettner M, Lehmensiek V, Dehmel T, Mausberg AK, von Geldern G, Gold R, Kümpfel T, Hohlfeld R, Mäurer M, et al. 2015. Natalizumab exerts a suppressive effect on surrogates of B cell function in blood and CSF. Mult Scler J 21: 1036-1044.

Warren KG, Catz I, Johnson E, Mielke B. 1994. Anti-myelin basic protein and anti-proteolipid protein specific forms of multiple sclerosis. Ann Neurol 35: 280-289. 


\section{J.J. Sabatino et al.}

Weber MS, Prod'homme T, Youssef S, Dunn SE, Rundle CD Lee L, Patarroyo JC, Stüve O, Sobel RA, Steinman L, et al. 2007. Type II monocytes modulate T cell-mediated central nervous system autoimmune disease. Nat Med 13: 935-943.

Weber MS, Prod'homme T, Patarroyo JC, Molnarfi N, Karnezis T, Lehmann-Horn K, Danilenko DM, Eastham Anderson J, Slavin AJ, Linington C, et al. 2010. B-cell activation influences T-cell polarization and outcome of anti-CD20 B-cell depletion in central nervous system autoimmunity. Ann Neurol 68: 369-383.

Winger RC, Zamvil SS. 2016. Antibodies in multiple sclerosis oligoclonal bands target debris. Proc Natl Acad Sci 113: 7696-7698.
Yang M, Sun L, Wang S, Ko K. 2010. Cutting edge: Novel function of B cell-activating factor in the induction of IL10-producing regulatory B cells. J Immunol 184: 3321 3325

Zanotti C, Chiarini M, Serana F, Sottini A, Garrafa E, Torri F, Caimi L, Rasia S, Capra R, Imberti L. 2012. Peripheral accumulation of newly produced $\mathrm{T}$ and $\mathrm{B}$ lymphocytes in natalizumab-treated multiple sclerosis patients. Clin Immunol 145: 19-26.

Zhou D, Srivastava R, Nessler S, Grummel V, Sommer N Brück W, Hartung HP, Stadelmann C, Hemmer B. 2006. Identification of a pathogenic antibody response to native myelin oligodendrocyte glycoprotein in multiple sclerosis. Proc Natl Acad Sci 103: 19057-19062. 


\section{$\&_{\mathrm{CSH}}^{\infty} \&$ Cold Spring Harbor

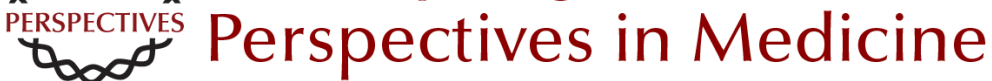

\section{B-Cell Therapies in Multiple Sclerosis}

Joseph J. Sabatino, Jr., Scott S. Zamvil and Stephen L. Hauser

Cold Spring Harb Perspect Med 2019; doi: 10.1101/cshperspect.a032037 originally published online January 22, 2018

\section{Subject Collection Multiple Sclerosis}

Multiple Sclerosis Pathology

Hans Lassmann

Regulatory T Cells: From Discovery to

Autoimmunity

Alexandra Kitz, Emily Singer and David Hafler

The Multiple Roles of B Cells in Multiple Sclerosis

and Their Implications in Multiple Sclerosis

Therapies

Rui Li and Amit Bar-Or

Autologous Hematopoietic Stem Cell

Transplantation in the Treatment of Multiple

Sclerosis

Carolina A. Rush, Harold L. Atkins and Mark S.

Freedman

B-Cell Therapies in Multiple Sclerosis

Joseph J. Sabatino, Jr., Scott S. Zamvil and Stephen L. Hauser

Oral Therapies for Multiple Sclerosis Simon Faissner and Ralf Gold

Interferon $\beta$ for Multiple Sclerosis

Dejan Jakimovski, Channa Kolb, Murali

Ramanathan, et al.

Alemtuzumab as Treatment for Multiple Sclerosis Serafeim Katsavos and Alasdair Coles
Natalizumab: Perspectives from the Bench to

Bedside

Afsaneh Shirani and Olaf Stüve

Daclizumab Therapy for Multiple Sclerosis Bibiana Bielekova

Lifestyle and Environmental Factors in Multiple

Sclerosis

Lars Alfredsson and Tomas Olsson

Biomarkers in Multiple Sclerosis

Anu Paul, Manuel Comabella and Roopali Gandhi

The Evolving Mechanisms of Action of Glatiramer

Acetate

Thomas Prod'homme and Scott S. Zamvil

Regulation of Astrocyte Functions in Multiple Sclerosis

Michael A. Wheeler and Francisco J. Quintana

Experimental Autoimmune Encephalomyelitis

(EAE) as Animal Models of Multiple Sclerosis (MS)

Simon Glatigny and Estelle Bettelli

Neurodegeneration in Progressive Multiple

Sclerosis

Graham Campbell and Don Mahad

For additional articles in this collection, see http://perspectivesinmedicine.cshlp.org/cgi/collection/ 